\title{
Blended Learning-Based Self-Regulated Learning in Table Tennis Learning
}

\author{
Dian Budiana*, Yusup Hidayat, Burhan Hambali, and \\ Gifran Rihla Gifarka Latief \\ Departemen Pendidikan Olahraga \\ Universitas Pendidikan Indonesia \\ Bandung, Indonesia \\ *dianbudiana@upi.edu
}

\author{
Cep Ubad Abdullah \\ Departemen Pendidikan Pariwisata \\ Universitas Pendidikan Indonesia \\ Bandung, Indonesia
}

\begin{abstract}
It is commonly known that learning in the revolution era 4.0 should utilize information and communication technology (ICT) and physical education, particularly table tennis learning, has no exception. This study integrated a social medium for learning namely Edmodo and Self-Regulated Learning (SRL) to develop self-confidence, motivation, selfindependence, and basic skills of table tennis learning. To measure whether the use of Edmodo-based SRL model influence the development of self-confidence, motivation, selfindependence, and basic skills in learning table tennis, this study administered a t-test in two classes; one experimental class implementing Edmodo in learning table tennis and one control class not implementing Edmodo in learning table tennis. In addition to t-test, this study also employed observation and questionnaire on self-confidence, motivation, self-independence, and basic skills of table tennis. The results of the study showed that SRL model utilizing Edmodo gave a significant influence on the development of students' self-confidence, motivation, selfindependence, and basic skills of table tennis.
\end{abstract}

Keywords: self-regulated learning, blended learning, selfconfidence, motivation, learning independence, basic skills

\section{INTRODUCTION}

Education promoting lifelong learning requires its students to have self-independence since it plays a key role in their learning development [1]. In addition to self-independence in learning, they also need to have self-confidence since it is a positive behavior to be able to express their abilities. It is also defined as self-faith that one has an ability to reach the goals set [2]. Along with self-independence and self-confidence, motivation also plays an important role for students in succeeding in their learning. Motivation mainly functions as a drive for them to make a maximum effort. It is common that good motivation often leads to good learning outcome [3]. In relation to learning, particularly learning table tennis, it is assumed that students with self-independence, self-confidence, and motivation will have good basic skills of table tennis.

All the three important aspects of self-independence, selfconfidence, and motivation are interrelated to each other. It is each individual's effort which plays the most significant part in maximizing each aspect. In learning, there is a model which is able to optimize individual role in learning namely Self-
Regulated Learning (SRL). The core of this learning model is where individuals work to be able to achieve the goals [4].

In the era of industrial revolution 4.0, education is required to meet the global needs. Therefore, educators all over the world should be able to participate in the virtual community, social media platforms, and other online networking to acquire ideas supporting their teaching [5]. Nowadays, there have been a variety of innovations in learning development; one of which is e-learning.

A study showed that learning using Edmodo, a social media platform particularly designed for learning, had a positive impact on students' participation in learning. It was found that students utilizing Edmodo had a higher score in comparison with those did not. This indicated that Edmodo had positive impacts, not only in students' academic achievements but also in their learning involvement and behaviors [6].

Considering the aforementioned reasons, this study aimed to identify the impacts of Edmodo-based SRL learning model towards students' self-confidence, motivation, selfindependence, and basic skills in table tennis learning in Physical Education Study Program, Faculty of Sport and Health Education, Universitas Pendidikan Indonesia Indonesia. It is expected that the results of this study are going to benefit teachers especially in creating novel innovations implementing blended learning - based SRL.

\section{RESEARCH METHOD}

This study employed a quasi-experimental design with pretest post-test control groups. The sampling technique used was non-probability sampling which was purposive sampling. In the meantime, the instrument selected was questionnaire and the data analysis method was performed using SPSS.

\section{A. Research Design}

This study was quantitative research. To identify the implementation effectiveness of blended learning, this study used average comparison test whose samples were divided into two classes consisting of experimental group (the group with blended learning) and control group (the group without blended learning). 
B. The Impact of Blended Learning - Based SRL Toward Learning Independence

It is known that population is a generalization containing subjects/ objects with certain quality or characteristics set by researchers to analyze and finally deduce [7]. In this study, the population was all students of Physical Education Study Program, Faculty of Sport and Health Education, Universitas Pendidikan Indonesia, Indonesia, class of 2007. However, the sample was the students taking table tennis learning course.

\section{Research Instruments}

Variables to analyze in this study were self-confidence, learning self-independence, motivation, and basic skills of table tennis. To be able to measure those variables, this study used an instrument of Learning Independence developed by Hidayati \& Listyani Hidayati \& Listyani [8]. The type of instrument was questionnaire identifying the level of learning independence. In the meantime, the identify the selfconfidence, this study used an instrument developed by Putri [9]. The instrument was questionnaire identifying the level of students' self-confidence in learning.

\section{RESULTS AND DISCUSSION}

The main purpose of the study was to investigate the relationship among the research variables. The data analysis technique used was t-test with the significance level of $\alpha$ at 0.05 , meaning that if the Sig. (2-tailed) is more than or equal to $\alpha$, Ho is accepted, and if Sig. (2-tailed) is less than $\alpha$, then Ho is rejected.

\section{A. Blended Learning - Based Impact Toward Self- Confidence}

TABLE I. ANALYSIS RESULTS OF SELF-CONFIDENCE OF EXPERIMENTAL GROUP AFTER USING BLENDED LEARNING IN SELFREGULATED LEARNING MODEL

\begin{tabular}{|c|c|l|l|}
\hline & \multicolumn{1}{|c|}{ Mean } & \multicolumn{1}{|c|}{ Std. Deviation } & Std. Error Mean \\
\hline Pre-test & 138,1667 & 11,40840 & 3,29332 \\
\hline Post-test & 148,1667 & 12,29067 & 3,54801 \\
\hline
\end{tabular}

TABLE II. ANALYSIS RESUlTS OF SELF-CONFIDENCE OF CONTROL GROUP WITHOUT USING BLENDED LEARNING IN SELF-REGULATED LEARNING MODEL

\begin{tabular}{|c|l|l|l|}
\hline & \multicolumn{1}{|c|}{ Mean } & \multicolumn{1}{|c|}{ Std. Deviation } & \multicolumn{1}{c|}{ Std. Error Mean } \\
\hline Pre-test & 134,2500 & 5,81729 & 1,67931 \\
\hline Post-test & 140,4167 & 9,69028 & 2,79734 \\
\hline
\end{tabular}

It was found that the average score of students' selfconfidence had an increase as much as 10.0 in the experimental group. Table 2 showed that the average score on pre-test was 134.25 and that on post-test was 140.41 . Therefore, the average score increase of the control group was 6.4. This results indicated that the experimental group outperformed the control group in terms of self-confidence as shown by the difference of the increasing average score.
TABLE III. ANALYSIS RESULTS OF LEARNING SELF-INDEPENDENCE OF EXPERIMENTAL GROUP AFTER USING BLENDED LEARNING IN SELFREGULATED LEARNING MODEL

\begin{tabular}{|l|l|l|l|}
\hline & \multicolumn{1}{|c|}{ Mean } & \multicolumn{1}{c|}{ Std. Deviation } & \multicolumn{1}{c|}{ Std. Error Mean } \\
\hline Pre-test & 80,50 & 4,421 & 1,276 \\
\hline Post-test & 89,66 & 2,87096 &, 82878 \\
\hline
\end{tabular}

TABLE IV. ANALYSIS RESULTS OF LEARNING SELF-INDEPENDENCE OF CONTROL GROUP WITHOUT USING BLENDED LEARNING IN SELFREGULATED LEARNING MODEL

\begin{tabular}{|l|l|l|l|}
\hline & \multicolumn{1}{|c|}{ Mean } & \multicolumn{1}{c|}{ Std. Deviation } & \multicolumn{1}{c|}{ Std. Error Mean } \\
\hline Pre-test & 77,41 & 5,68024 & 1,63974 \\
\hline Post-test & 79,75 & 6,468 & 1,867 \\
\hline
\end{tabular}

Tables 3 and 4 showed that the learning self-independence of the experimental group increased as much as 9.16. In the meantime, the increase of average score of the control group was 2.34 which is smaller than that of the experimental group. Therefore, it was proven that students with blended learning had higher increase of learning self-independence in comparison with students without blended learning.

\section{The Impact of Blended Learning - Based Toward Motivation}

TABLE V. ANALYSIS RESUlTS OF MOTIVATION OF EXPERIMENTAL GROUP AFTER USING BLENDED LEARNING IN SELF-REGULATED LEARNING MODEL

\begin{tabular}{|l|l|l|l|}
\hline & \multicolumn{1}{|c|}{ Mean } & \multicolumn{1}{c|}{ Std. Deviation } & Std. Error Mean \\
\hline Pre-test & 80,67 & 8,228 & 2,375 \\
\hline Post-test & 86,33 & 8,272 & 2,388 \\
\hline
\end{tabular}

TABLE VI. ANALYSIS RESUlts OF MOTIVATION OF CONTROL GROUP AFTER WITHOUT BLENDED LEARNING IN SELF-REGULATED LEARNING MODEL

\begin{tabular}{|l|l|l|l|}
\hline & \multicolumn{1}{|c|}{ Mean } & \multicolumn{1}{c|}{ Std. Deviation } & Std. Error Mean \\
\hline Pre-test & 77,25 & 6,19567 & 1,78854 \\
\hline Post-test & 80,50 & 8,11844 & 2,34359 \\
\hline
\end{tabular}

It has been shown by both tables 5 and 6 that the average score increase in the experimental group was as much as 5.66. Meanwhile, that in the control group was 2.25 . Thus, it can be inferred that students with blended learning had better motivation compared to those without blended learning.

\section{The Impact of Blended Learning - Based SRL Toward Basic Skills of Table Tennis}

TABLE VII. ANALYSIS RESUlTS OF TABLE TENNIS BASIC SKILlS OF EXPERIMENTAL GROUP AFTER USING BLENDED LEARNING IN SELFREGULATED LEARNING MODEL

\begin{tabular}{|l|l|l|l|}
\hline & \multicolumn{1}{|c|}{ Mean } & \multicolumn{1}{c|}{ Std. Deviation } & \multicolumn{1}{c|}{ Std. Error Mean } \\
\hline Pre-test & 31,75 & 9,27484 & 2,67742 \\
\hline Post-test & 61,16 & 17,86227 & 5,15639 \\
\hline
\end{tabular}




\section{REFERENCES}

TABLE VIII. ANALysis RESUlts of TABLE TENNIS BASIC SKILlS OF CONTROL GROUP WITHOUT BLENDED LEARNING IN SELF-REGULATED LEARNING MODEL

\begin{tabular}{|l|l|l|l|}
\hline & \multicolumn{1}{|c|}{ Mean } & \multicolumn{1}{|c|}{ Std. Deviation } & \multicolumn{1}{c|}{ Std. Error Mean } \\
\hline Pre-test & 44,50 & 18,23832 & 5,26495 \\
\hline Post-test & 60,75 & 16,00639 & 4,62065 \\
\hline
\end{tabular}

It has been revealed in tables 7 and 8 that the increasing average score of the experimental group was higher (29.41) in comparison with that of the control group (16.25). This indicated that the members of the experimental groups outperformed those in the control group in the context of table tennis basic skills.

The analytical results of this study have proven that Blended Learning - Based Self-Regulated Learning Model was effective in improving the quality of self-confidence, motivation, learning independence, and basic skills in table tennis learning. This in in line with other previous studies such as one analyzing the effectiveness of blended learning towards self-confidence by Rizqi, Suyitmo, and Sudarmin [10], the effectiveness of blended learning towards learning independence by Maathoba [11], blended learning towards learning motivation by Syarif [12], and blended learning towards basic skills by Zou et al. [13] proving that all those variables have been increased due to the implementation of blended learning.

\section{CONCLUSION}

Based on the results of the study, it can be concluded that the use of blended learning utilizing Edmodo in SRL model is effective in improving the quality of self-confidence, learning independence, motivation, and basic skills in table tennis learning for students of Physical Education Study Program, Faculty of Sport and Health Education, Universitas Pendidikan Indonesia, Indonesia.
[1] van Hout-Wolters, B., Simons, R. J., \& Volet, S. (2000). Active learning: Self-directed learning and independent work. In New learning (pp. 21-36). Springer, Dordrecht.

[2] Juliantine, T. (2012). Penilaian dalam pendidikan jasmani. Jurnal Pendidikan Olahraga, 1(8), 1-12.

[3] I Saputra, Y. N. (2018). Pentingnya Menumbuhkan Motivasi Belajar Siswa. 10.31227/osf.io/z83w4.

[4] Zimmerman, B. J. (2002). Becoming a Self-Regulated Learner: An Overview. Theory Into Practice, 41(2), 64-70

[5] Trust T (2017) Motivation, Empowerment, and Innovation: Teachers' Beliefs About How Participating in the Edmodo Math Subject Community Shapes Teaching and Learning, Journal of Research on Technology in Education, 49:1-2, 16-30, DOI: 10.1080/15391523.2017.1291317

[6] Charoenwet, S., \& Christensen, A. (2016). The effect of Edmodo learning network on students' perception, self-regulated learning behaviors and learning performance. no. Imsci, 297-300.

[7] Sugiyono. 2017. Metode Penelitan Kuantitatif, Kualitatif, dan R\&D. Bandung: Alfabeta, CV.

[8] Hidayati, K., \& Listyani, E. (2010). Improving Instruments of Students' Self-regulated learning. Jurnal Penelitian Dan Evaluasi Pendidikan, 14(1).

[9] Putri, N. D. A. (2016). Pengaruh Kepercayaan Diri Terhadap Prokrastinasi Akademik Mahasiswa (Doctoral dissertation, University of Muhammadiyah Malang).

[10] Rizqi, A.A., Suyitno, H., \& Sudarmin (2016). Analisis Kemampuan Komunikasi Matematis Ditinjau dari Kepercayaan Diri Siswa melalui Blended learning. Unnes Journal of Mathematics Education Research. http://journal.unnes.ac.id/sju/index.php/ujmer

[11] Maathoba, A. (2017). Pengembangan Sistem Pembelajaran Blended Learning pada Matakuliah Grafika Komputer untuk Meningkatkan Kemandirian Belajar Mahasiswa di Jurusan Teknik Elektro Universitas Negeri Malang. SKRIPSI Jurusan Teknik Elektro-Fakultas Teknik UM.

[12] Syarif, I (2012). Pengaruh Penerapan Model Blended Learning Terhadap Motivasi Dan Prestasi Belajar Siswa SMKN 1 Paringin (Doctoral dissertation, Tesis. Yogyakarta: Universitas Negeri Yogyakarta).

[13] Zou, J., Liu, Q., \& Yang, Z. (2012). Development of a Moodle course for schoolchildren's table tennis learning based on Competence Motivation Theory: Its effectiveness in comparison to traditional training method. Computers \& Education, 59(2), 294-303. 